\title{
Comparison of the photoprotective effect between hydrolyzed and aglycones flavonoids as sunscreen: A systematic review
}

\author{
Yessica Andrea Monsalve-Bustamante, Miguel Angel Puertas-Mejia, Juan Camilo Mejia-Giraldo* \\ Grupo de Investigación en Compuestos Funcionales, Facultad de Ciencias Exactas y Naturales, Universidad de Antioquia UdeA, Medellin, Colombia.
}

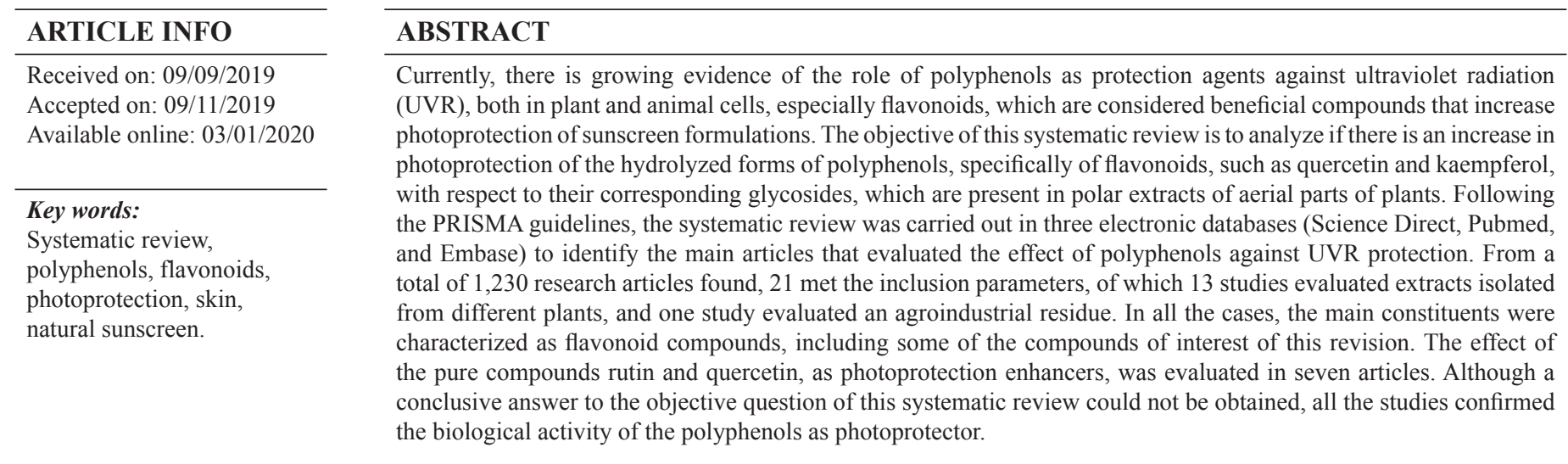

\section{INTRODUCTION}

Since in 1820 , Widmark discovered the role played by sunlight in skin burns, it has been working on various strategies that can minimize the harmful effect of solar radiation on humans. Since then, the damage caused to living beings by exposure to ultraviolet radiation (UVR) has been studied, which has led to a desire to develop increasingly effective and safe substances that evolve the history of sunscreens (Urbach, 2001). The effects of UVR on the skin are diverse, and depend mainly on the duration of the exposure and the wavelength. In this sense, one of the acute effects of the UVR on the skin, specifically the UVB (290-320 nm), consists in sunburn (erythema), which if severe enough, can produce blisters and destruction of the superficial layers of the skin, with secondary infection and systemic effects,

"Corresponding Author

Juan Camilo Mejia-Giraldo, Grupo de Investigación en Compuestos Funcionales, Facultad de Ciencias Exactas y Naturales, Universidad de Antioquia UdeA, Medellin, Colombia.E-mail: juan.mejia8@udea.edu.co similar to a first- or second-degree heat burn. Furthermore, UVA radiation $(320-400 \mathrm{~nm})$ produces tanning, thickening of the stratum corneum, epidermis, and dermis, local and systemic immunosuppression, photokeratitis, and photoconjunctivitis, among others. In addition, the chronic changes due to UVR produce photoaging, induction of pre-malignant changes and malignant skin tumors, and so on (Kuchel et al., 2003; Samaniego et al., 2017).

Therefore, to prevent the effects of UVR exposure, topical sunscreens have been developed, with active ingredients that absorb or scatter radiation in the harmful UV range (wavelengths of 290-400 nm) that reaches the earth's surface (Food and Drug Administration, 2012). In addition, these compounds must have attributes, such as photostability greater than $80 \%$ and must not penetrate the skin where they may cause adverse effects. Commercial sunscreens contain chemical filters (organic substances, which absorb UVA and UVB radiation) or physical filters (inorganic substances, which reflect or disperse UVA and UVB radiation) and mostly present a combination of both (Schalka and Reis, 2011; Serpone et al., 2007). 
In this regard, several studies have demonstrated that plant extracts have various biological properties, such as antioxidant, anti-inflammatory, immunomodulatory, antimutagenic, and photoprotective, which have been justified by the presence of polyphenolic compounds (De Oliveira-Júnior et al., 2017; Greul et al., 2002). Polyphenols are important compounds in plants, which constitute a wide variety of secondary metabolites that include flavonoids, phenolic acids, tannins, lignans and coumarins, among others (Costa et al., 2015; Dai and Mumper, 2010). Then, based on their chemical structure, phenolic compounds act as scavenger of reactive oxygen species (ROS), which are produced in excess under oxidative stress. In addition, polyphenols play an important role as sunscreens and protect plants against high exposure to UVR (Agati et al., 2013; Agati and Tattini, 2010; Bendová et al., 2007; Jansen et al., 1998).

Within the phenolic compounds, the flavonoids constitute a large and diverse group of secondary metabolites in the plants, with their basic structure of C6-C3-C6 ring represented, mainly by the glycosides of quercetin and kaempferol, which accumulate in the plants in the which fulfill a large number of functions (Agati et al., 2013; Gitelson et al., 2017; Harborne and Williams, 2000). Thereby, flavonoids perform a determining role mainly as a defense mechanism against the harmful effects of UVR in plants, and consequently improve the photosynthetic resistance against UVA and UVB radiation from solar spectrum. In addition, as mentioned, they act as free radical scavengers, with characteristics that could benefit current sunscreens, with a summing or synergic effect on their photoprotective potential (Agati et al., 2011; 2013; Nagula and Wairkar, 2019). Consequently, this review aims to determine the role of quercetin and kaempferol in photoprotection, analyzing the studies carried out in plant extracts during the last 20 years. The main objective was to analyze relevant information where the aglycone form of such polyphenols is studied and their role in terms of photoprotection and photostability with application in humans, in comparison to their corresponding glycosides.

\section{MATERIALS AND METHODS}

This systematic review included the articles from three databases: Pubmed, Science Direct, and Embase, since 1998 to the end of October 2018.

\section{Search terms}

According to the research question, three main themes were identified: "skin, "photoprotection," and "polyphenols"; the latter were specified as "rutin," "quercetin," and "kaempferol"; also included are the terms "glycosides OR glucosides," "hydrolysis of glycosides OR glucosides," and the keywords "photoprotection OR fotoprotector" are used to formulate a search strategy that is applied in all the searches on the databases. Further relevant studies were identified through manual searches of reference lists. Studies have been first screened by title, then by abstract, and finally by reading of the full text.

\section{Inclusion and exclusion criteria}

Besides the search terms, articles were selected based on certain inclusion and exclusion criteria. The first one, peer reviewed journal articles were being included, whereas reviews, editorial material, meeting abstracts, letters, retracted publications, and book chapters were excluded. To be incorporated, the studies had to explore and assess at least one type of polyphenol or plant extract where photoprotection to be evaluated with application in humans. The language of the articles included was only English.

\section{Quality evaluation}

The quality of the studies selected was assessed in a systematic form. The quality score is composed of five items, and each item is allocated 0,1 , or 2 points for each category: quantification of flavonoids or polyphenols, characterization of extracts, photoprotection tests in vitro, ex vivo, and in vivo, in humans or animals. In total, each study can be awarded a maximum of 10 points.

\section{Parameters evaluation of quality}

Test of polyphenols and flavonoids

- If no polyphenols or flavonoids quantification test is performed: 0 points

- If a test of quantification of polyphenols or flavonoids is carried out: 1 point

- If polyphenols and flavonoids are quantified: 2 points

\section{Chemical characterization of molecules of interest}

- If the polyphenols are not characterized: 0 points

- If at least one specific molecule of interest is characterized: 1 point

- If they characterize or work with more than one molecule of our interest (rutin, quercetin, kaempferol): 2 points

Photoprotection tests in vitro

- If in vitro photoprotection tests are not carried out: 0 points

- If in vitro photoprotection tests are carried out: 1 point

- If in vitro photoprotection and photostability tests are carried out: 2 points

Photoprotection tests ex vivo

- If ex vivo photoprotection tests are not carried out: 0 points

- If ex vivo photoprotection tests are carried out: 1 point

- If ex vivo photoprotection and cytotoxicity or dermotoxicity tests are carried out: 2 points

Photoprotection tests in vivo in humans or animals

- If in vivo photoprotection tests are not carried out in humans or animals: 0 points

- If in vivo photoprotection tests are carried out on animals: 1 point

- If in vivo photoprotection tests are carried out in humans: 2 points

\section{Quality ranges}

High: $8-10$ points

Average: 4-7 points

Low: 0-3 points 


\section{Data extraction}

The quantitative and qualitative data were extracted from all the included publications: authors, year of publication, country of origin, information about the objectives, and main findings of each study. The analysis of the information was carried out by three experts in the subject, who evaluated the reproducibility and the risk of bias in each phase of the review.

\section{RESULTS}

\section{Selection of studies}

The search of the information in databases resulted in the identification of a total of 1,230 records (research papers that met the selection criteria) from the initial searches, the reference lists and the elimination of duplicate records. After the exhaustive selection of the studies, 21 final studies were included. Figure 1 shows the flowchart of the present study with the inclusion and exclusion criteria. All studies were in the English language and were published between January 1998 and October 2018.

\section{Characteristics of the studies}

Among the articles included and analyzed, 13 of them evaluated the photoprotective effect of the plant extracts (Aquino et al., 2002; Bonina et al., 2002; 2000; Costa et al., 2015; De Oliveira-Júnior et al., 2017; Gajardo et al., 2016; Mejía-Giraldo et al., 2015; 2016a; 2016b; Puertas-mejía et al., 2015; Reis Mansur et al., 2016; Silva et al., 2016; Velasco et al., 2008), one study evaluated polyphenols in an agroindustrial waste (Mandalari et al., 2013), and seven of the studies evaluated rutin and quercetin pure in photoprotective formulations (De Oliveira et al., 2015; Graziola et al., 2016; Kamel and Mostafa, 2015; Kostyuk et al., 2018; Peres et al., 2015; Tomazelli et al., 2018; Vicentini et al., 2010). For the analysis of polyphenols, tests were carried out as total polyphenol content (TPC) or flavonoid content, antioxidant capacity by different methods, and in plant extracts their main compounds were chemically characterized. In addition, different in vitro, ex vivo, and in vivo photoprotection and photostability tests were carried out. Table 1 describes the main characteristics of each study, including the year of implementation, country, objectives, polyphenols, and the species of the plant used.

\section{Results of individual studies}

All studies promote the photoprotective capacity of polyphenols. A common denominator was the incorporation of these polyphenols into cosmetic formulations for the tests of interest, in which their effect was compared with antioxidants,
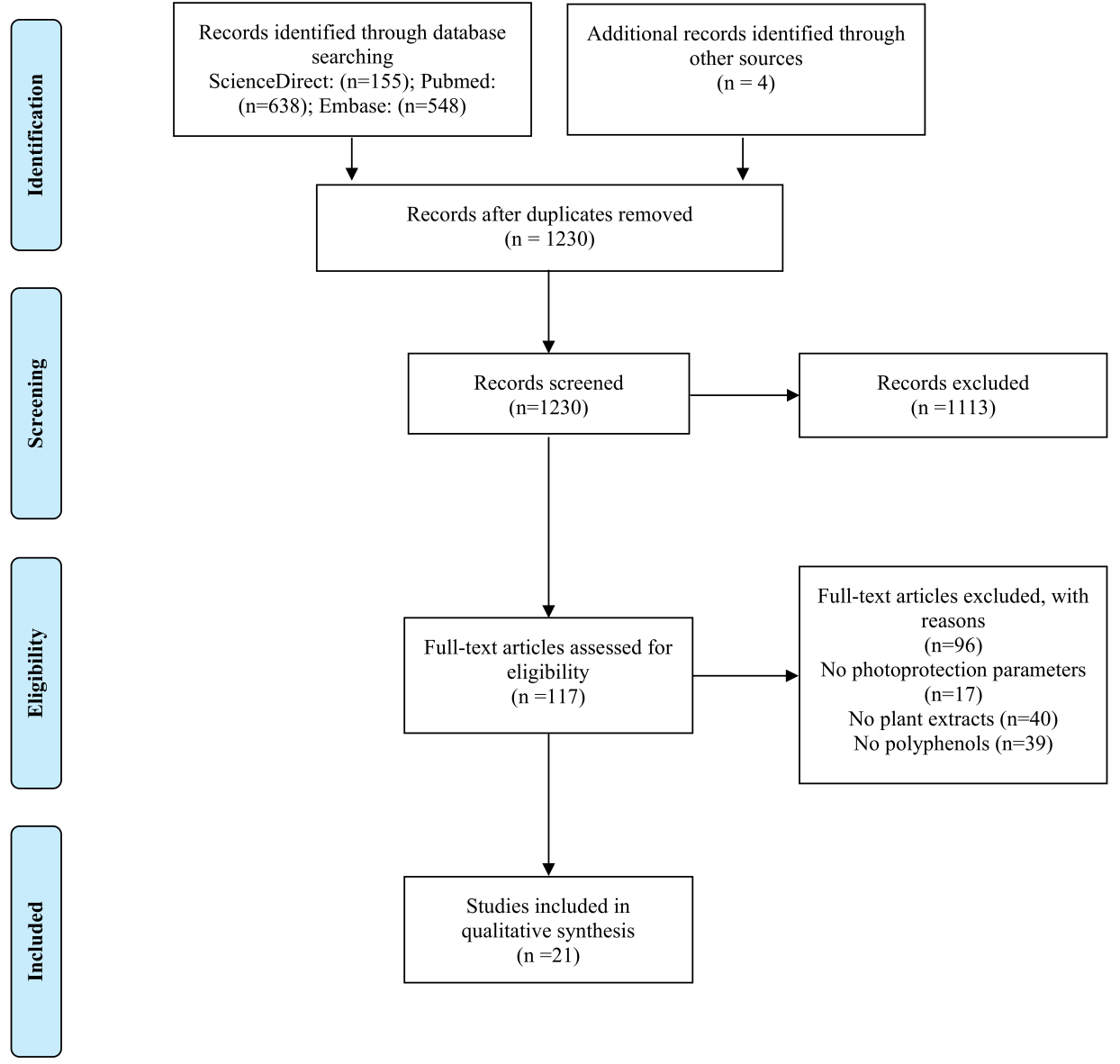

Figure 1. Flowchart of selection of studies. 
Table 1. Summary of the main characteristics of the studies evaluated.

\begin{tabular}{|c|c|c|c|c|c|}
\hline Ref & Year & Country & Objetive & Polyphenols & Species \\
\hline (Kostyuk et al., 2018) & 2018 & Belarus & $\begin{array}{l}\text { Propose a panel of in vitro methods for the preselection } \\
\text { of natural photoprotective substances with high } \\
\text { photostability and low phototoxicity. }\end{array}$ & $\begin{array}{l}\text { Rutin } \\
\text { Quercetin }\end{array}$ & $\begin{array}{l}\text { Does not apply, pure } \\
\text { compounds }\end{array}$ \\
\hline (Tomazelli et al., 2018) & 2018 & Brazil & $\begin{array}{l}\text { To evaluate the SPF of the rutin by in vitro and in vivo } \\
\text { methods, comparing sunscreen formulations containing } \\
0.1 \%(\mathrm{w} / \mathrm{w}) \text { rutin, } 3.0 \%(\mathrm{w} / \mathrm{w}) \text { avobenzone and } 8.0 \% \\
\text { (w/w) octyldimethyl PABA with a similar preparation free } \\
\text { of active substances. }\end{array}$ & Rutin & $\begin{array}{l}\text { Does not apply, pure } \\
\text { compounds }\end{array}$ \\
\hline (De Oliveira-Júnior et al., 2017) & 2017 & Brazil & $\begin{array}{l}\text { To evaluate the photoprotective effect of cosmetic } \\
\text { formulations containing hydroalcoholic extract of } \\
\text { N. variegate. }\end{array}$ & Quercetin & Neoglaziovia variegata \\
\hline (Gajardo et al., 2016) & 2016 & Chile & $\begin{array}{l}\text { To investigate SPF and the antioxidant properties of } \\
\text { Parastrephia lepidophyla Cabr., Fabiana squamata Phil., } \\
\text { Ephedra chilensis K.Presl., Lampaya medicinalis Phil., } \\
\text { Baccharis tola Phil., And compact Azorella Phil. }\end{array}$ & $\begin{array}{l}\text { Quinic caffeic acid, apigenin- } \\
\text { di-C-hexoside (vicenin II), } \\
\text { apigenin-C-hexoside-C- } \\
\text { pentoside, rutin pentoside, } \\
\text { quercetin-dihexoside, dicaffeic } \\
\text { quinic acid (isomer), caffeine }\end{array}$ & $\begin{array}{l}\text { Parastrephia lepidophyla } \\
\text { Cabr., Fabiana squamata Phil., } \\
\text { Ephedra chilensis K.Presl., } \\
\text { Lampaya medicinalis } \text { Phil., } \\
\text { Baccharis tola } \text { Phil., and } \\
\text { Azorella compacta } \text { Phil. }\end{array}$ \\
\hline (Graziola et al., 2016) & 2016 & Brazil & $\begin{array}{l}\text { To investigate the use of flavonoid rutin as an alternative } \\
\text { to glutaraldehyde to cross-link gelatin microparticles. }\end{array}$ & Rutin & $\begin{array}{l}\text { Does not apply, pure } \\
\text { compounds }\end{array}$ \\
\hline (Silva et al., 2016) & 2016 & Brazil & $\begin{array}{l}\text { To evaluate the photoprotective capacity of the crude } \\
\text { extract of } S \text {. purpurea } L \text {. peel, against UVA and UVB rays } \\
\text { in vitro and its incorporation into a sunscreen formulation } \\
\text { as an active principle. }\end{array}$ & $\begin{array}{l}\text { HHDP-allioil-glucose, Galoil- } \\
\text { bis-HHPD-glucose, rutin, } \\
\text { Quercetin }\end{array}$ & Spondias purpurea \\
\hline (Mejía-Giraldo et al., 2016b) & 2016 & Colombia & $\begin{array}{l}\text { To evaluate the photoprotective, photostability and } \\
\text { antioxidant activity of leaf extracts of } B \text {. antioquensis, as } \\
\text { well as its phenolic composition. }\end{array}$ & $\begin{array}{l}\text { Quercetin, rutin, kaempferol, } \\
\text { chlorogenic acid }\end{array}$ & Baccharis antioquensis \\
\hline (Reis Mansur et al., 2016) & 2016 & Brazil & $\begin{array}{l}\text { To develop a photoprotective oil-in-water emulsion of } \\
\text { Bauhinia microstachya var. }\end{array}$ & $\begin{array}{l}\text { kaempferol-3-O- ramnoside, } \\
\text { astragalina-2 ", 6" -di-O- } \\
\text { digalato }\end{array}$ & $\begin{array}{l}\text { Bauhinia microstachya var. } \\
\text { massambabensis Vaz, Fabaceae }\end{array}$ \\
\hline (Mejía-Giraldo et al., 2016a) & 2016 & Colombia & $\begin{array}{l}\text { To evaluate the photoprotective and antioxidant capacity } \\
\text { in vitro and correlate it with the content of polyphenol and } \\
\text { anthocyanin in nine plants. }\end{array}$ & Polyphenols & $\begin{array}{l}\text { Sphagnum meridense, } \\
\text { Calamagrostis effusa, } \\
\text { Lycopodiella alopecuroides, } \\
\text { Morella parvifolia, Baccharis } \\
\text { antioquensis, Pentacalia } \\
\text { pulchella, Castilleja fissifolia, } \\
\text { Hesperomeles ferruginea and } \\
\text { Hypericum juniperinum }\end{array}$ \\
\hline (De Oliveira et al., 2015) & 2015 & Brazil & $\begin{array}{l}\text { To develop and evaluate the effectiveness of sunscreens } \\
\text { containing benzophenone- } 3 \text { or avobenzone with and } \\
\text { without rutin. }\end{array}$ & Rutin & $\begin{array}{l}\text { Does not apply, pure } \\
\text { compounds }\end{array}$ \\
\hline (Costa et al., 2015) & 2015 & Brazil & $\begin{array}{l}\text { To investigate the potential of the ethanol extract of } M \text {. } \\
\text { taxifolia as an active ingredient in a photoprotective } \\
\text { formulation with sunscreen (UVA-UVB). }\end{array}$ & Quercetin & Marcetia taxifolia \\
\hline (Peres et al., 2015) & 2015 & Brazil & $\begin{array}{l}\text { Investigate the synergistic effect of rutin associated with } \\
\text { organic UV filters. }\end{array}$ & Rutin & $\begin{array}{l}\text { Does not apply, pure } \\
\text { compounds }\end{array}$ \\
\hline (Kamel and Mostafa, 2015) & 2015 & Egypt & $\begin{array}{l}\text { Development of rutin nanoparticulate photoprotective } \\
\text { preparations. }\end{array}$ & Rutin & $\begin{array}{l}\text { Does not apply, pure } \\
\text { compounds }\end{array}$ \\
\hline (Puertas-Mejía et al., 2015) & 2015 & Colombia & $\begin{array}{l}\text { To evaluate the in vitro UVR absorption capacity of } \\
\text { extracts from three plants belonging to the Ericaceae } \\
\text { family and compare them with their antioxidant capacity. }\end{array}$ & Polyphenols & $\begin{array}{l}\text { Bejaria aestuans, Cavendishia } \\
\text { pubescens y Cavendishia } \\
\text { bracteata }\end{array}$ \\
\hline (Mejía-Giraldo et al., 2015) & 2015 & Colombia & $\begin{array}{l}\text { To evaluate the photoprotective and antioxidant capacity } \\
\text { of Sphagnum meridense extract. In addition, try different } \\
\text { extraction procedures to evaluate their effects on the } \\
\text { excretion of phenolic compounds. }\end{array}$ & Polyphenols & Sphagnum meridense \\
\hline (Mandalari et al., 2013) & 2013 & Italy & $\begin{array}{l}\text { To evaluate the antioxidant and photoprotective effect } \\
\text { of blanch water, a by-product of the almond processing } \\
\text { agroindustry. }\end{array}$ & $\begin{array}{l}\text { Naringenin-7-O-glucoside and } \\
\text { kaempferol-7-O-rutinoside. }\end{array}$ & Agua blanch \\
\hline (Vicentini et al., 2010) & 2010 & Brazil & $\begin{array}{l}\text { Consider the histological aspects to evaluate the } \\
\text { photoprotective effect in vivo of a w/o microemulsion } \\
\text { containing quercetin against the skin damage induced by } \\
\text { UVB radiation. }\end{array}$ & Quercetin & $\begin{array}{l}\text { Does not apply, pure } \\
\text { compounds }\end{array}$ \\
\hline (Velasco et al., 2008) & 2008 & Brazil & $\begin{array}{l}\text { To develop delivery systems of bioactive sunscreen } \\
\text { containing rutin, Passiflora incarnata L. and Plantago } \\
\text { lanceolate extracts, associated or not with organic and } \\
\text { inorganic UV filters. }\end{array}$ & Rutin, Polyphenols & $\begin{array}{l}\text { Passiflora incarnata } \mathrm{L} \text {. and } \\
\text { Plantago lanceolata } \text { extracts }\end{array}$ \\
\hline
\end{tabular}


Table 1. (Continued)

\begin{tabular}{|c|c|c|c|c|c|}
\hline Ref & Year & Country & Objetive & Polyphenols & Species \\
\hline (Aquino et al., 2002) & 2002 & Italy & $\begin{array}{l}\text { To evaluate the antioxidant effect in vitro and the } \\
\text { photoprotective activity in vivo of an ethanolic leaf extract } \\
\text { of Culcitium reflexum H.B.K. }\end{array}$ & $\begin{array}{l}\text { Rutin, quercetin-3-O-D- } \\
\text { galactopyranoside-4-O-D- } \\
\text { glucopyranoside, quercetin- } \\
\text { 3-O-D-glucopyranoside, } \\
\text { isorhamnetin-3-O-D- } \\
\text { galactopyranoside, quercetin } \\
\text { and kaempferol. }\end{array}$ & Culcitium reflexum \\
\hline (Bonina et al., 2002) & 2002 & Italy & $\begin{array}{l}\text { To evaluate the antioxidant effect in vitro and the } \\
\text { photoprotective activity in vivo of a lyophilized extract of } \\
\text { Capparis spinosa L. obtained by methanolic extraction of } \\
\text { the flowering buds. }\end{array}$ & Quercetin, Kaempferol & Capparis spinosa \\
\hline (Bonina et al., 2000) & 2000 & Italy & $\begin{array}{l}\text { To evaluate the antioxidant effect in vitro and the } \\
\text { photoprotective effect on the skin of three freeze- } \\
\text { dried extracts obtained from the juice of the leaves of } \\
\text { S. telephium } L \text {. }\end{array}$ & Quercetin, Kaempferol & Sedum telephium \\
\hline
\end{tabular}

SPF: Sun Protection Factor

UV filters, and polyphenols, such as quercetin and rutin or their additive; evaluating its possible applicability as sunscreens. Table 2 describes the main findings of the individually studies.

\section{Evaluation of the quality of the studies}

The evaluation of the quality of each study based on the inclusion and exclusion criteria was indicated in Table 3, according to the selected characteristics. The total average score was $4.6 \pm$ 1.2. Thus, for articles where extracts were analyzed, an average quality of $4.5 \pm 1.3$ was presented and for studies evaluating specific polyphenols, such as rutin, quercetin, or kaempferol, an average quality of $4.9 \pm 1.0$ was found. Although it is not an excellent quality, in relation to the parameters defined by our self, these results indicated a sufficient level of quality to examine the conclusions in a valid way.

\section{DISCUSSION}

\section{Summary of results}

The main objective of the research was to carry out a systematic review of the evidence about the effect of hydrolyzed polyphenols, such as quercetin and kaempferol, on photoprotection and photostability, determining if they are better or not regarding these characteristics in comparison to their glycosides. It should be noted that none of the articles evaluated could find an analysis that may solve the propose question. However, in the research described by Kostyuk et al. (2018), the rutin is compared with its respective aglycone quercetin, finding better values for quercetin in some of analyzes carried out (Kostyuk et al., 2018). Nevertheless, all the analyzed papers showed that the photoprotective effect of plant extracts rich in polyphenols, especially flavonoids and their additive and synergistic effects when mixed with commercial sunscreens improve significantly the SPF and photostability of these formulations (Peres et al., 2015; Tomazelli et al., 2018).

\section{Explanation of the results}

Previous studies have proven that the photoprotective capacity of vegetable extracts is due to the presence of polyphenols, and especially flavonoids, such as rutin, quercetin, kaempferol, among others (Aquino et al., 2002; Costa et al., 2015; Gajardo et al., 2016; Mejía-Giraldo et al., 2016b; Silva et al., 2016). In addition, some authors have demonstrated that polyphenols could avoid the damage induced by the UVR, through mechanisms, such as capture and inactivation of ROS. It also increases its photostability, due to an additive effect produced by high polyphenolic antioxidant capacity and a co-active effect, so that antioxidants do not absorb radiation (Greul et al., 2002).

De Oliveira-Junior et al. (2017) found that after incorporation of Nv-HA (Hydro Alcoholic extract of Neoglaziovia variegata) into $\mathrm{O} / \mathrm{W}$ emulsions, no photoprotective activity was presented for concentrations at $5.0 \%$ of Nv-HA (SPF $=0.008 \pm$ $0.013)$ and $10.0 \%(\mathrm{SPF}=0.059 \pm 0.057)$. However, the extracts were able to maximize the protective effect of the formulations that contained synthetic filters $(5.43 \pm 0.07$ and $11.73 \pm 0.04)$ extract concentrations of 0.5 and $1.0 \%(\mathrm{v} / \mathrm{v})$, respectively in a dose-response behavior. When compared to quercetin (SPF = $2.45 \pm 0.13)$ and benzophenone-3 $(\mathrm{SPF}=5.10 \pm 0.15)$, the NvHA extract at $1.0 \%$, showed the highest photoprotective effect. Likewise, the results propose that Nv-HA extract may be utilized as a coadjuvant or booster of chemical filters when added in a cosmetic sunscreen, reducing the necessary amount of synthetic filters, and therefore, lowering the risks of phototoxic reactions without affecting the photoprotective property of the formulation (De Oliveira-Júnior et al., 2017).

In addition, the molecules that prevent skin erythema produced by exposure to UVB, such as antioxidant and antiinflammatory molecules, could significantly improve the UV protection of sunscreens, as demonstrated by Tomazelli et al. (2018) with the results of the in vivo SPF test, in which the formulation containing rutin, enhance the SPF by approximately $70 \%$, compared to the rutin free formulation in a mixture with the UV filters (butylmethoxydibenzoylmethane and octyl dimethyl). This fact is evidence of the improvement in photoprotection efficiency, even at low concentration, decreasing significantly the formation of erythema, effects associated probably to its anti-inflammatory activity (Peres et al., 2015; Tomazelli et al., 2018). Similarly, the use of plant extracts mixed with chemical or physical sunscreens has shown that it can protect the skin more effectively against UV rays by preserving skin matrix damage against oxidative stress, and synergistically increasing the SPF of single filter formulations (De Oliveira-Júnior et al., 2017). Thus, Aquino et al. (2002) demonstrated that the beneficial 
Table 2. Individual main findings.

\begin{tabular}{|c|c|}
\hline Reference & Main findings \\
\hline (De Oliveira-Júnior et al., 2017) & $\begin{array}{l}\text { After evaluating the photoprotective activity of } \mathrm{Nv}-\mathrm{HA} \text {, the extract was incorporated into cosmetic formulations and its photoprotective efficacy } \\
\text { was also investigated. Compared with quercetin }(\mathrm{SPF}=2.45 \pm 0.13) \text { and benzophenone- } 3(\mathrm{SPF}=5.10 \pm 0.15), \mathrm{Nv}-\mathrm{HA} 1.0 \%(\mathrm{SPF}=11.73 \pm 0.04) \text { the } \\
\text { extract had the greatest photoprotective effect. Which suggests that the extract have a superior effect than the molecules alone. }\end{array}$ \\
\hline (Costa et al., 2015) & $\begin{array}{l}\text { All formulations containing Marcetia taxifolia extract had an } \mathrm{SPF} \geq 6 \text {; with SPF values near to benzophenone- } 3 \text { a chemical filter frequently used as a } \\
\text { component of sunscreens. These results indicated the possibility of using these extracts as sunscreen in pharmaceutical preparations. }\end{array}$ \\
\hline (Mejía-Giraldo et al., 2015) & $\begin{array}{l}\text { The extract of Sphagnum meridense showed hopeful values of UVAPF of } 2 \text {, UVA/UVB ratio of } 0.697 \text {, critical wavelength }(\lambda \mathrm{c}) \text { of } 384 \mathrm{~nm} \text { and in vitro } \\
\text { antioxidant capacity, similar values compared to common sunscreens. }\end{array}$ \\
\hline (Mejía-Giraldo et al., 2016a) & $\begin{array}{l}\text { The extracts of } P \text {. pulchella and } B . \text { antioquensis could be the origin of promising and photostable new ingredients for use in sunscreens. In addition, } \\
\text { they may exert an antioxidant and photoprotective effect on the skin by reducing oxidative stress related with aging mechanisms. }\end{array}$ \\
\hline (Reis Mansur et al., 2016) & $\begin{array}{l}\text { Leaf extracts of Bauhinia microstachya var. massambabensis were integrated into } \mathrm{O} / \mathrm{W} \text { emulsions containing commercial photoprotectors, without } \\
\text { contributing to photodegradation of the sunscreen, when exposed to UV radiation. All the formulations showed an adequate SPF and both plant } \\
\text { extracts boosted the photoprotective result, as an improvement in the SPF in vivo; therefore, they could be considered safe for cosmetic use. }\end{array}$ \\
\hline (Aquino et al., 2002) & $\begin{array}{l}\text { The EIP of the crude extract of Culcitium reflexum H.B.K. leaves was compared with the TOC in a gel formulation, finding in the extract an EIP of } \\
43.5 \% \text { and TOC of } 21.7 \% \text {, demonstrating its possible applicability in photoprotection. }\end{array}$ \\
\hline (Velasco et al., 2008) & $\begin{array}{l}\text { It was found that broad-spectrum sun protection is achieved when the dried extract of Passiflora incarnata } \mathrm{L} \text {. was in the presence of } 7.0 \%(\mathrm{w} / \mathrm{w}) \\
\text { of ethylhexyl methoxycinnamate, } 2.0 \%(\mathrm{w} / \mathrm{w}) \text { benzophenone- } 3 \text { and } 2.0 \%(\mathrm{w} / \mathrm{w}) \text { of } \mathrm{TiO}_{2} \text {. This shows additive effect of the extract in the increase of } \\
\text { photoprotection in a system delivery. }\end{array}$ \\
\hline (Gajardo et al., 2016) & $\begin{array}{l}\text { The Baccharis tola extract has sun protection properties, as well as antioxidant and regenerative activities. Two cosmetic products were developed } \\
\text { and subjected to several tests of quality control and stability tests, showing remarkable stability and absence of pathogenic microorganisms. }\end{array}$ \\
\hline (Bonina et al., 2002) & $\begin{array}{l}\text { When the extracts were compared with TOC, the EIP values were } 59.6 \% \text { and } 22.0 \% \text { for gel formulations of Capparis spinosa L. and TOC, } \\
\text { respectively. This methanolic extract provides excellent photoprotection to UVB induced skin disturbance. Therefore, it could have important } \\
\text { applications as a component in cosmeceutical products used in skin alterations, propitiated or sharpened by ROS and the overproduction of free } \\
\text { radicals. }\end{array}$ \\
\hline (Silva et al., 2016) & $\begin{array}{l}\text { The crude shell extract of Spondias purpurea provided photoprotective activity against UVB (SPF } 43.78 \pm 0.19 \mathrm{in} \mathrm{dilution} \text { of } 50 \mathrm{mg} / \mathrm{mL} \text { of ethanol) } \\
\text { and UVA (this protection was comparated with rutin and benzophenone- } 3 \text {, used as patterns). The phenolic content was } 28.68 \pm 0.046 \mathrm{mg} \mathrm{GAE} / \mathrm{g} \text { and } \\
\text { flavonoid content of } 2.64 \pm 0.005 \mathrm{mg} \mathrm{EQ} / \mathrm{g} \text { extract. The antioxidant activity showed inhibition percentage of } 74.41 \text {, with EC } \mathrm{EC}_{50} 27.11 \mathrm{~g} / \mathrm{mL} \text {. }\end{array}$ \\
\hline (Bonina et al., 2000) & $\begin{array}{l}\text { The results obtained in vitro and in vivo test show that both the total freeze-dried juice and the freeze-dried lipophilic fraction of the leaves of Sedum } \\
\text { telephium L., have photoprotective effects against induced skin alterations by the UVB rays. }\end{array}$ \\
\hline (Mejía-Giraldo et al., 2016b) & $\begin{array}{l}\text { The characteristics of in vitro photoprotection and the antioxidant activity of the extracts of } B \text {. antioquensis are demonstrated, as well as its broad- } \\
\text { spectrum UVA-UVB protection with excellent sensory and photoprotective characteristics. Thus, it can be deduced that it is feasible to employ the } \\
\text { extract of B. antioquensis as a natural ingredient with photoprotective and antioxidant properties. }\end{array}$ \\
\hline (Puertas-Mejía et al., 2015) & 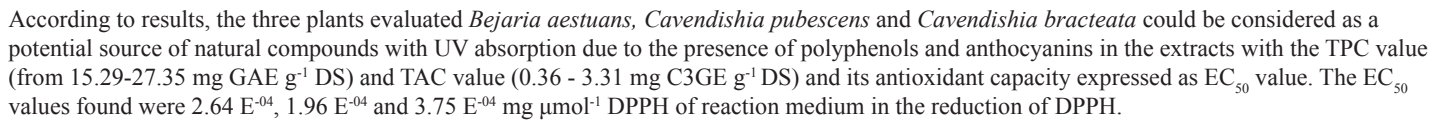 \\
\hline (Mandalari et al., 2013) & $\begin{array}{l}\text { The EIP of blanch water, a byproduct of the almond processing industry is compared to TOC in a gel formulation; giving the extrac an EIP of } 50.5 \% \\
\text { and TOC of } 22.4 \% \text {; these results demonstrated an effect of Blanch Water against photooxidative damage in vivo. }\end{array}$ \\
\hline (De Oliveira et al., 2015) & $\begin{array}{l}\text { Rutin addition to UVA filters supplier antioxidant properties to the formulations and were considered safe for human use. It should be noted that rutin } \\
0.1 \%(\mathrm{w} / \mathrm{w}) \text { plus benzophenone } 6.0 \%(\mathrm{w} / \mathrm{w}) \text { increased the SPF from } 24.3 \pm 1.5 \text { to } 33.3 \pm 2.9 \text {. Besides, the SPF enhanced after irradiation as was the } \\
\text { case with the control. Nevertheless, this did not happen with blend of rutin and butyl methoxydibenzoylmethane. }\end{array}$ \\
\hline (Graziola et al., 2016) & $\begin{array}{l}\text { The SPF results of dispersions containing M0, MG or MR, free or in combination with commercial UV filters (benzophenone- } 3 \text { and octyl } \\
\text { methoxycinnamate) indicated that the microspheres (M0, MG or MR) } 5.0 \%(\mathrm{w} / \mathrm{w}) \text { had no photoprotective impact in vitro, and presented no influence } \\
\text { on the evaluated efficacy when mixed with UV filters. However, in vivo studies proved that these materials had excellent skin compatibility. }\end{array}$ \\
\hline (Vicentini et al., 2010) & $\begin{array}{l}\text { According to the analyzes carried out, it was found that } \mathrm{ME}+\mathrm{Q} \text { is a promising photochemoprotective agent with applicability in humans. This due to } \\
\mathrm{ME}+\mathrm{Q} \text { managed to reduce the histological damage caused by UV radiation to which they were subjected in hairless mice. }\end{array}$ \\
\hline (Kostyuk et al., 2018) & $\begin{array}{l}\text { It was possible identify some photostable and nonphototoxic substances, principally phenylpropanoids and glycosylated flavonoids, with UVA } \\
+ \text { UVB physical, chemical and biological broad-spectrum protection. }\end{array}$ \\
\hline (Peres et al., 2015) & $\begin{array}{l}\text { The association of rutin and UVB filters enhanced notably the critical wavelengths of formulations, evincing a photoprotective improvement } \\
\text { particularly in the UVA range, presenting this compound as a striking adjuvant for anti-UVB sunscreen. }\end{array}$ \\
\hline (Kamel and Mostafa, 2015) & $\begin{array}{l}\text { The evaluation of designed nanoemulsions demonstrated the improvement of photoprotection effect of the flavonoid rutin, when mixed with common } \\
\text { physical sunscreen such as } \mathrm{TiO}_{2} \text {. }\end{array}$ \\
\hline (Tomazelli et al., 2018) & $\begin{array}{l}\text { The rutin has proven to be an excellent antioxidant when mixed with UVA and UVB filters as Butyl methoxydibenzoylmethane (avobenzone) and } \\
\text { Octyl dimethyl PABA, besides being stable and safe to use in sunscreen formulations. }\end{array}$ \\
\hline
\end{tabular}

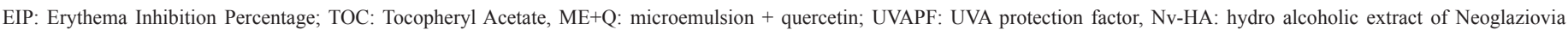

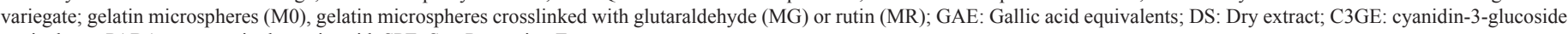
equivalents; PABA: para-aminobenzoic acid, SPF: Sun Protection Factor.

photoprotective effect of the extract of Culcitium reflexum, which could be related to its antioxidant activity in vitro and, in turn, to the content of biophenols, where the EIP (Erythema Inhibition Percentage) was 43.5 compared to 21.7 of the TOC (Tocopheryl Acetate) a recognized antioxidant agent (Aquino et al., 2002).
On the other hand, in the study described by Kostyuk et al. (2018) compares the photoprotective effect of quercetin and rutin. There, an SPF of $5.71 \pm 0.12$ and a UVA/UVB ratio of 1.5 were found for quercetin $(10 \%)$, while the values for the rutin $(10 \%)$ were SPF of $3.44 \pm 0.16$ and UVA/UVB of 1.2 , which demonstrated the 
Table 3. Quality criteria.

\begin{tabular}{|c|c|c|c|c|c|c|}
\hline \multicolumn{7}{|c|}{ Quality criteria } \\
\hline \multirow{2}{*}{ Ref. } & \multirow{2}{*}{$\begin{array}{l}\text { Test of polyphenols } \\
\text { and/or total flavonoids }\end{array}$} & \multirow{2}{*}{ Molecules of interest } & \multicolumn{2}{|c|}{ Photoprotection tests } & \multirow{2}{*}{$\begin{array}{l}\text { Photoprotection tests in } \\
\text { humans or animals in vivo }\end{array}$} & \multirow{2}{*}{ Total } \\
\hline & & & in vitro & ex vivo & & \\
\hline (De Oliveira-Júnior et al., 2017) & 2 & 2 & 1 & 0 & 0 & 5 \\
\hline (Costa et al., 2015) & 1 & 2 & 1 & 0 & 0 & 4 \\
\hline (Mejía-Giraldo et al., 2015) & 1 & 0 & 2 & 0 & 0 & 3 \\
\hline (Mejía-Giraldo et al., 2016a) & 1 & 0 & 2 & 0 & 0 & 3 \\
\hline (Reis Mansur et al., 2016) & 0 & 0 & 2 & 1 & 2 & 5 \\
\hline (Aquino et al., 2002) & 1 & 2 & 1 & 0 & 2 & 6 \\
\hline (Velasco et al., 2008) & 1 & 2 & 1 & 0 & 0 & 4 \\
\hline (Gajardo et al., 2016) & 0 & 2 & 1 & 2 & 0 & 5 \\
\hline (Bonina et al., 2002) & 1 & 2 & 1 & 0 & 2 & 6 \\
\hline (Silva et al., 2016) & 2 & 2 & 2 & 0 & 0 & 6 \\
\hline (Bonina et al., 2000) & 0 & 2 & 0 & 0 & 2 & 4 \\
\hline (Mejía-Giraldo et al., 2016b) & 1 & 2 & 2 & 0 & 0 & 5 \\
\hline (Puertas-Mejía et al., 2015) & 1 & 0 & 1 & 0 & 0 & 2 \\
\hline (Mandalari et al., 2013) & 1 & 2 & 1 & 0 & 2 & 6 \\
\hline (De Oliveira et al., 2015) & 0 & 2 & 2 & 0 & 2 & 6 \\
\hline (Graziola et al., 2016) & 0 & 2 & 1 & 0 & 2 & 5 \\
\hline (Vicentini et al., 2010) & 0 & 2 & 0 & 2 & 1 & 5 \\
\hline (Kostyuk et al., 2018) & 0 & 2 & 2 & 2 & 0 & 6 \\
\hline (Peres et al., 2015) & 0 & 2 & 2 & 0 & 0 & 4 \\
\hline (Kamel and Mostafa, 2015) & 0 & 2 & 1 & 0 & 0 & 3 \\
\hline (Tomazelli et al., 2018) & 0 & 2 & 1 & 0 & 2 & 5 \\
\hline
\end{tabular}

Mean: $4.6 \pm 1.2$.

predominant absorption of quercetin in the UVA region. In addition, the photostability of both polyphenols was analyzed, finding the $\mathrm{SPF}$ of the rutin stable $(\mathrm{SPF}=5.25 \pm 0.13)$ against $\mathrm{UV}$ irradiation (66 \% UVA and $33 \% \mathrm{UVB}$ ) of $0-6.0 \mathrm{~J} / \mathrm{cm}^{2}$, while the quercetin passed from an SPF of $4.31 \pm 0.10$ to $3.16 \pm 0.20$ under the same conditions, demonstrating the photostability of the rutin (Kostyuk et al., 2018). This case is the only one that could be conclusive with respect to the research question, but because it is a single study and it is also not specific regarding the research topic, it could not be conclusive to answer the objective question of this review.

Finally, the analysis of this review showed us that there remains a broad field of research in terms of the photoprotective capacity of natural products and their applications in cosmetic formulations, and how it can support the evolution of sunscreens and to correct their possible adverse effects, through an improvement in their effectiveness, safety and photostability, which could be attributed to natural products modified with safe, affordable, and economical procedures.

\section{CONCLUSION}

This review attempted to systematically analyze the current evidence on the photoprotective effects of glycosylated polyphenols and aglycones. A total of 21 studies were included in this review, which 13 of them evaluated plant extracts, one article studied an industrial waste and seven analyzed rutin and quercetin in cosmetic formulations. The results and analysis of the scientific literature suggest that the studies included in this review provide evidence of the protective effect of natural products. However, there are no specific investigations that can determine whether hydrolyzed polyphenols, such as quercetin and kaempferol, could improve the photoprotective effect and photostability with respect to their glycosides, which leaves a gap in this field of phytochemical research.

\section{ACKNOWLEDGMENTS}

The authors acknowledge CODI-Universidad de Antioquia (Project No. CIQF 290) for financial support. Monsalve, Y.A., acknowledges master fellowship granted by SAPIENCIAAlcaldía de Medellín. The authors would like to thank the International Passages Support Fund-Universidad de Antioquia.

\section{CONFLICT OF INTEREST}

The authors declare that they have no conflicts of interest.

\section{REFERENCES}

Agati G, Biricolti S, Guidi L, Ferrini F, Fini A, Tattini M. The biosynthesis of flavonoids is enhanced similarly by UV radiation and root zone salinity in L. vulgare leaves. J Plant Physiol, 2011; 168:204-12.

Agati G, Brunetti C, Di Ferdinando M, Ferrini F, Pollastri S, Tattini M. Functional roles of flavonoids in photoprotection: new evidence, lessons from the past. Plant Physiol Biochem, 2013; 72:35-45.

Agati G, Tattini M. Multiple functional roles of flavonoids in photoprotection. New Phytol, 2010; 186:786-93.

Aquino R, Morelli S, Tomaino A, Pellegrino ML, Saija A, Grumetto L, Bonina F. Antioxidant and photoprotective activity of a crude extract of Culcitium reflexum H.B.K. leaves and their major flavonoids. J Ethnopharmacol, 2002; 79:183-91. 
Bendová H, Akrman J, Krejčí A, Kubáč L, Jírová D, Kejlová K, Malý M. In vitro approaches to evaluation of Sun Protection Factor. Toxicol In Vitro, 2007; 21:1268-75.

Bonina F, Puglia C, Aquino RP, Sacchi A. In vitro antioxidant and in vivo photoprotective effects of a lyophilized extract of Capparis spinosa L. buds. J Cosmet Sci, 2002; 53:321-35.

Bonina F, Puglia C, Tomaino A, Saija A, Mulinacci N, Romani A, Vincieri F. In-vitro antioxidant and in-vivo photoprotective effect of three lyophilized extracts of Sedum telephium L. leaves. J Pharm Pharmacol, $2000 ; 5: 1279-85$.

Costa SCC, Detoni CB, Branco CRC, Botura MB, Branco A. In vitro photoprotective effects of Marcetia taxifolia ethanolic extract and its potential for sunscreen formulations. Revista Brasileira de Farmacognosia, $2015 ; 25: 413-18$.

Dai J, Mumper RJ. Plant Phenolics: Extraction, Analysis and Their Antioxidant and Anticancer Properties. Molecules, 2010; 15:7313-52.

De Oliveira AC, Peres DAlmeida D, Mendes Rugno C, Kojima M, Sales de Oliveira Pinto CA. Functional photostability and cutaneous compatibility of bioactive UVA sun care products. J Photochem Photobiol B, 2015; 148:154-59.

De Oliveira-Júnior RG, Souza GR, Ferraz CAA, de Oliveira AP, Araújo CS, de Lima-Saraiva SRG, Reis SAGB, Gonçalves TM, Rolim LA, Rolim-Neto PJ, César FCS, Almeida JRGDS. Development and evaluation of photoprotective $\mathrm{O} / \mathrm{W}$ emulsions containing hydroalcoholic extract of Neoglaziovia variegata (Bromeliaceae). Sci World J, 2017; 2017:5019458

Food and Drug Administration (FDA). Guidance for industry labeling and effectiveness testing: sunscreen drug products for over-the-counter human use-small entity compliance guide, Silver SpringMaryland, Estados Unidos. 2012.

Gajardo S, Stowhas T, Salas F, Quispe C, Buc-calderon P, Benites J. Determination of sun protection factor and antioxidant properties of six Chilean Altiplano plants. Blacpma, 2016; 15:352-63.

Gitelson A, Chivkunova, O, Zhigalova, T, Solovchenko A. In situ optical properties of foliar flavonoids: implication for non-destructive estimation of flavonoid content. J Plant Physiol, 2017; 218:258-64.

Graziola F, Candido TM, De Oliveira CA, Peres DD, Issa MG, Mota J, Rosado C, Consiglieri VO, Kaneko TM, Robles Velasco MV, Baby AR. Gelatin-based microspheres crosslinked with glutaraldehyde and rutin oriented to cosmetics. Braz J Pharm Sci, 2016; 52:603-12.

Greul AK, Grundmann JU, Heinrich F, Pfitzner I, Bernhardt J, Ambach A, Biesalski HK, Gollnick H. Photoprotection of UV-Irradiated Human Skin: an antioxidative combination of vitamins E and C, carotenoids, selenium and proanthocyanidins. Skin Pharmacol Physiol, 2002; 15: 307-15.

Harborne JB, Williams CA. Advances in flavonoid research since 1992. Phytochemistry, 2000; 55:481-504.

Jansen MA, Gaba V, Greenberg BM. Higher plants and UV-B radiation: balancing damage, repair and acclimation. Trends Plant Sci, 1998; 3:131-5

Kamel R, Mostafa DM. Rutin nanostructured lipid cosmeceutical preparation with sun protective potential. J Photochem Photobiol B, 2015; 153:59-66.

Kostyuk V, Potapovich A, Albuhaydar AR, Mayer W. Natural substances for prevention of skin photoaging: screening systems in the development of sunscreen and rejuvenation cosmetics. Rejuvenation Res, 2018; 21:91-101.

Kuchel JM, Barnetson RSC, Halliday GM. Nitric oxide appears to be a mediator of solar-simulated ultraviolet radiation-induced immunosuppression in humans. J Invest Dermatol, 2003; 121:587-93.

Mandalari G, Arcoraci T, Martorana M, Bisignano C, Rizz, L, Bonina FP, Trombetta D, Tomaino A. Antioxidant and photoprotective effects of blanch water, a byproduct of the almond processing industry. Molecules (Basel, Switzerland), 2013; 18:12426-40.

Mejía-Giraldo JC, Gallardo C, Puertas-Mejía MA. In vitro photoprotection and antioxidant capacity of Sphagnum meridense extracts, a novel source of natural sunscreen from the mountains of Colombia. Pure Appl Chem, 2015; 87:961-70.
Mejía-Giraldo JC, Henao-Zuluaga K, Gallardo C, Atehortúa L, Puertas-Mejía MA. Novel in vitro antioxidant and photoprotection capacity of plants from high altitude ecosystems of Colombia. Photochem Photobiol, 2016a; 92:150-7.

Mejía-Giraldo JC, Winkler R, Gallardo C, Sánchez-Zapata AM, Puertas-Mejía MA. Photoprotective potential of Baccharis antioquensis (Asteraceae) as natural sunscreen. Photochem Photobiol, 2016b; 92: $742-52$

Nagula RL, Wairkar S. Recent advances in topical delivery of flavonoids: a review. J Control Release, 2019; 296:190-201.

Peres DA, De Oliveira CA, Tokunaga VK, Mota J P, Rosado C, Consiglieri VO, Kaneko TM, Velasco MV, Baby AR. Rutin increases critical wavelength of systems containing a single UV filter and with good skin compatibility. Skin Res Technol, 2015; 22:325-33

Puertas-Mejía MA, Rincón-Valencia S, Mejía-Giraldo JC Screening of UVA / UVB absorption and in vitro antioxidant capacity of Bejaria aestuans, Cavendishia pubescens and Cavendishia bracteata leaf extracts. Res J Med Plant, 2015; 9:435-41.

Reis Mansur MC, Guimarães Leitão S, Cerqueira-Coutinho C Vermelho AB, Silva RS, Presgrave OAF, Leitão AAC, Leitão GG, RicciJúnior E, Santos EP. In vitro and in vivo evaluation of efficacy and safety of photoprotective formulations containing antioxidant extracts. Braz J Pharmacognosy, 2016; 26:251-58.

Samaniego Rascón D, Ferreira AD, Gameiro da Silva M. Cumulative and momentary skin exposures to solar radiation in central receiver solar systems. Energy, 2017; 137:336-49.

Schalka S, Silva dos Reis VM. Sun protection factor: meaning and controversies. An Bras Dermatol, 2011, 86:507-15.

Serpone N, Dondi D, Albini A. Inorganic and organic UV filters: their role and efficacy in sunscreens and suncare products. Inorganica Chim Acta, 2007; 360:794-802.

Silva RV, Costa SCC, Branco CRC, Branco A. In vitro photoprotective activity of the Spondias purpurea L. peel crude extract and its incorporation in a pharmaceutical formulation. Ind Crops Prod, 2016 83:509-14.

Tomazelli LC, de Assis Ramos MM, Sauce R, Cândido TM, Sarruf FD, de Oliveira Pinto CAS, de Oliveira CA, Rosado C, Velasco MVR, Baby AR. SPF enhancement provided by rutin in a multifunctional sunscreen. Int J Pharm, 2018; 552:401-6.

Urbach F. The historical aspects of sunscreens. J Photochem Photobiol B, 2001; 64:99-104.

Velasco MV, Sarruf FD, Salgado-Santos IM, HaroutiounianFilho CA, Kaneko TM, Baby AR. Broad spectrum bioactive sunscreens. Int J Pharm, 2008; 363:50-7.

Vicentini FT, Fonseca YM, Pitol DL, Iyomasa MM, Bentley MV Fonseca MJ. Evaluation of protective effect of a water-in-oil microemulsion incorporating quercetin against UVB-induced damage in hairless mice skin J Pharm Pharm Sci, 2010; 13:274-85.

How to cite this article:

Monsalve-Bustamante YA, Puertas-Mejia MA, MejiaGiraldo JC. Comparison of the photoprotective effect between hydrolyzed and aglycones flavonoids as sunscreen: A systematic review. J Appl Pharm Sci, 2020; 10(1): $116-123$. 